\title{
Evaluation of Resistance to Bacterial Wilt and Verticillium Wilt in Eggplants (Solanum melongena L.) Collected in Malaysia
}

\author{
Yoshiteru Sakata, Shinji Monma, Tomoaki Narikawa* and Shoji Komochi** \\ National Research Institute of Vegetalbes, Omamental Plants and Tea (NIVOT) Ano, Mie, 514.23
}

\begin{abstract}
Summary
Sixty accessions of eggplants collected in Malaysia were evaluated for their resistance to bacterial wilt, Verticillium wiilt and Fusarium wilt, caused by Pseudomonas sola. nacearum, Verticillium dahliae and Fusarium oxysporum, respectively. In the evaluation of the field infected with $P$. solanacearum, more than $60 \%$ of the accessions were resistant. Based on the evaluation at the seedling stage of the resistant accessions, LS1934 was judged to be the most resistant accession to bacterial wilt, but most of the same accessions were not resistant to Verticillium wilt. LS2436 was the only accession with a relatively high resistance to Verticillium wilt. LS1934 and LS2436 were also resistant to Fusarium wilt.
\end{abstract}

\section{Introdution}

Bacterial wilt caused by Psendomonas solanacearum E. F. Smith is an economically important disease of eggplant (Solanum melongena L.) worldwide (Kelman, 1953). The bacteria can survive in soils in areas with temperate and warm climates (Kelman, 1953) and they can be the limiting factor for cultivation of this vegetable.

Verticillium wilt caused by Verticillium dahliae Kleb. is also an important disease of eggplant (Goth and Webb, 1981). The fungus can survive in soils for more than 14 years (Schnathorst, 1981) and can also be a limiting factor for cultivation of this vegetable in temperate areas (Snyder and Smith, 1981).

In areas infected with these organisms, the use of resistant varieties may achieve stable production. However, there are no resistant varieties of high quality. In Japan, grafting of eggplants onto resistant rootstocks such as 'Torvum vigor' (S. tor. vum Swartz) is widely practiced to avoid the damage caused by bacterial wilt and/or Verticillium

Received for publication 3 March 1995.

* Present address : Mitsui Toatsu Chemicals Inc. Kasumigaseki, 3-2-5. Chiyoda Tokyo 100.

* * Present address : Research Institute of Hokkai Kan Co. Ltd. Miyanosawa, 2-3-6-28, Nishi, Sapporo 063. wilt. However, the grafting procedure requires a certain expertise, and is time-consuming. Furthermore, the grafted seedlings must be grown at optimum temperature and humidity for the graft union to knit. Automatic grafting machines are being developed, but are not yet available. Therefore, breeding of resistant eggplant varieties is essential.

The authors have attempted to breed bacterial wilt-resistant eggplants based on Japanese standards (black fruit skin, black calyx, medium to small fruit size, weight about $100 \mathrm{~g}$ ) by using resistant gene(s) derived from 'Dingaras Multiple Purple' (Nath, 1975) and 'Nantou Qie' (Chinese variety). To obtain sources with higher resistance for further breeding, we screened our collection of eggplants as well as wild relatives for resistance to bacterial and Verticillium wilt. Several wild relatives were found to show a relatively high resistance to these diseases (unpublished data), but most of them exhibit a low or no compatibility with eggplant.

We report here the resistance of eggplant acces. sions to bacterial and Verticillium wilt, which were collected in Malaysia from 1985 to 1986 in cooperation with the Malaysian Agricultural Research and Development Institute (MARDI). In addition, these accessions were evaluated for 
Fusarium wilt resistance.

\section{Materials and Methods}

\section{Bacterial wilt}

\section{1) Evaluation in infected field}

In the summer of 1987,59 accessions of eggplants collected from Malaysia including some prickly wild type accessions, 3 susceptible cultivars, i.e. 'Italian Happy Globe' (Takii \& Co., Ltd. (S. aethiopicum L. (synonym $S$. integrifolium Poir.)), ' $F_{1}$ Caravan'('Taibyo VF' in Japanese; Takii \& Co., Ltd.), and 'Money Maker No. 2' ('Senryou 2 gou' in Japanese; Takii \& Co., Ltd.), and 3 resistant cultivars, i.e. 'Assist', 'F 1 Meet' (Takii \& Co., Ltd.), and 'Dingaras Multiple Purple', were evaluated in our experimental field heavily infected with $P$. solanacearum. 'Italian Happy Globe', ' $F_{1}$ Caravan', ' $F_{1}$ Meet', and 'Assist' were used as control rootstocks. ' $F_{1}$ Caravan', ' $F_{1}$ Meet', and 'Assist' are interspecific hybrids between $S$. melongena and $S$. aethiopicum. In most of the accessions, collected seeds were used directly. But some accessions with little amount of the collected seeds were used after propagation. Seeds were sown on 22 April 1987 in a greenhouse, and 10 seedlings of each accession were transplanted to the infected field on 12 June (7 weeks after sowing). Artificial inoculation was not attempted because the susceptible check 'Money Maker No. 2' was severely damaged in mid-July.

Each plant was scored on 22 August (10 weeks after transplanting to the infected field) for foliar symptoms on a 0 to 4 scale as follows : $0=$ no symptoms; $1=$ a few leaves wilted; $2=$ half of the leaves wilted; $3=$ almost all the leaves wilted; and $4=$ all the leaves wilted or the plant died.

2) Evaluation by artificial inoculation

In the summer of 1989,16 accessions which were highly resistant to bacterial wilt in the field evaluation (1987) were reevaluated at the seedling stage by artificial inoculation. Seeds of 16 accessions estimated as resistant and 5 checks listed in Table 3 were sown on 8 June 1989 and the seedlings were grown in a greenhouse.

Seedlings were inoculated on 18 July (6 weeks after sowing) with cultures of EBw 89 strain (isolated from infected eggplant) and E8570 strain (provided by Dr. Ozaki, Morioka Branch, NIVOT, Japan). The cultures were grown at $30{ }^{\circ} \mathrm{C}$ in
Wakimoto medium (Wakimoto, 1962). Two-day-old cultures were used directly as inocula after adjusting the bacterial concentration by the addition of tap water. The concentrations of the inocula in each strain were $1.5 \times 10^{10}$ cells $\cdot \mathrm{m} l^{-1}$ and $3.0 \times$ $10^{10}$ cells $\cdot \mathrm{m}^{-1}$, respectively. Twelve seedlings of each accesion were carefully removed from the nursery and washed with tap water. The root-tip of each plant was cut to two-thirds its length, and the roots were dip-inoculated with the inoculum. The inoculated seedlings were planted in a flat filled with sterilized soil and kept at a relatively high temperature $\left(24 \sim 35{ }^{\circ} \mathrm{C}\right)$ in a plastic-tunnel in a greenhouse. Foliar symptoms of each plant were scored into 5 grades as above evaluation on 30 Sept. (11 weeks after inoculation).

\section{Verticillium wilt}

Fifty-six accessions of eggplant collected from Malaysia, 5 susceptible cultivars, 'Italian Happy Globe', 'Assist', 'Dingaras Multiple Purple', 'Money Maker No. 2', and 'Nakate Shinkuro' and 2 resistant cultivars, ' $F_{1}$ Meet' and ' $F_{1}$ Caravan', were evaluated at the seedling stage for their resistance to Verticillium wilt. Five tests were performed at the seedling stage because of the differences in the collection time, poor quality, and small quantity of seeds. The accessions that were once estimated as resistant, based on the relatively low value of average disease indices, were tested at least twice to confirm their resistance. A schedule of the tests is listed in Table 1.

Inoculum for this evaluation was prepared by culturing No. 5 strain (isolated from strawberry) at $25{ }^{\circ} \mathrm{C}$ in potato glucose medium supplemented with $0.1 \%$ dibasic potasium phosphate and $0.3 \%$

Table 1. Schedule of tests for the evaluation of Verticillium wilt resistance.

\begin{tabular}{|c|c|c|c|}
\hline Test No. & Sowing & Inoculation & Evaluation \\
\hline I & '85 19 Dec. & '86 30 Jan. & '86 $24 \mathrm{Feb}$. \\
\hline II & '85 19 Dec. & '86 $14 \mathrm{Feb}$. & '86 11 Mar. \\
\hline III & '86 29 Oct. & '86 28 Nov. & '87 10 Jan. \\
\hline $\mathrm{IV}$ and $\mathrm{V}^{2}$ & '87 12 Mar. & '87 09 Apr. & '87 20 May \\
\hline$V$ and $\mathrm{X}^{\mathrm{z}}$ & '92 27 Jan. & '92 18 Mar. & '92 12 May \\
\hline VII & '89 24 Jan. & '8907 Apr. & '89 09 May \\
\hline YIII & '89 24 Jan. & '89 02 May & '89 02 June \\
\hline$X$ & '94 25 Feb. & '9407 Apr. & '94 09 May \\
\hline
\end{tabular}

z The tests were carried out simultaneously. 
yeast extract. Ten-day-old culture was used as inoculum after adjusting the spore concentration to $1.0 \sim 2.0 \times 10^{7}$ spores $\cdot \mathrm{m}^{-1}$. Seedlings were carefully removed from the nursery and washed with tap water. The root-tip of each plant was cut to two-thirds its length, and the roots were dip-inoculated with the inoculum. The inoculated seedlings were planted in a flat filled with sterilized soil, drenched with $10 \mathrm{ml}$ of inoculum to each plant, and grown in a greenhouse.

About one month after the inoculation, foliar symptoms of each plant were scored on a scale of 0 to 4 as follows : $0=$ no symptoms; $1=$ slight wilt and yellowing of the lowest leaves; $2=$ half of the leaves wilted or showed yellowing; $3=$ almost all the leaves wilted or showed yellowing; and $4=$ all the leaves wilted, showed yellowing or plant died.

\section{Fusarium wilt}

Two accessions of LS1934 and LS2436, which were highly resistant to bacterial and Verticillium wilt in this study, as well as a susceptible cultivar. 'Nantou Qie (LS 96)', were evaluated at the seedling stage for their resistance to Fusarium wilt. Seeds were sown on 16 Sept. 1992, and the seedlings were grown in a greenhouse.

Seedlings were inoculated on 28 Oct $(6$ weeks after sowing) with strain SUF 126 (provided by Dr. Umekawa, Kyushu Natl Agric. Exp. Stn, Japan) cultured at $25{ }^{\circ} \mathrm{C}$ in potato sucrose medium. Tenday-old culture was used as inoculum after adjusting the spore concentration to $1.2 \times 10^{7}$ spores $\cdot \mathrm{m} l$ -1 . Fifteen to thirty seedlings of each accession were carefully removed from the nursery, washed with tap water, and dip-inoculated as above. The inoculated seedlings were planted in a flat filled with sterilized soil, drenched with $5 \mathrm{ml}$ of inoculum to each plant, and grown in a greenhouse.

Foliar symptoms of each plant were scored on 25 Nov. (4 weeks after inoculation) on a 0 to 4 as follows : $0=$ no symptoms; $1=$ slight wilt and yellowing of the lowest leaves; 2 = half of the leaves wilted or showed yellowing; $3=$ almost all the leaves wilted or showed yellowing; and $4=$ all the leaves wilted, showed yellowing or plant died.

\section{Results and Discussion}

\section{Bacterial wilt}

1) Evaluation in infected field
Six weeks after transplanting to the infected field, the susceptible 'Italian Happy Globe', 'F 1 Caravan', and 'Money Maker No. 2' were severely damaged by bacterial wilt (data not shown). In the final observation, 10 weeks after transplanting, they were completedly destroyed by the pathogen. After six weeks, the disease indices of the resistant cultivars 'Assist', ' $F_{1}$ Meet', and 'Dingaras Multiple Purple' were $0.80,0.60$, and 0.00 , respectively; in the final observation, the values were $3.60,3.90$, and 0.00 . 'Assist' and ' $F_{1}$ Meet' that were resistant to bacterial wilt were not fully resistant in the heavily infected field. Only 'Dingaras Multiple Purple' seemed to be highly resistant in the evaluation (Table 2).

Twenty-seven accessions which did not show any symptoms even in the final observation were considered to be highly resistant. Nine accessions with a disease index of less than 1.00 also appeared to be resistant. In total, 36 accessions or more than $60 \%$ of the tested accessions were deemed resistant.

\section{2) Evaluation by artificial inoculation}

To select accessions with a higher resistance among the resistant accessions detected in the evaluation in the infected field, seedlings were inoculated with bacterial suspensions with more than $10^{10}$ cells $\cdot \mathrm{m} l^{-1}$ (Table 3 ). The inoculation conditions were so drastic that even the resistant check 'Dingaras Multiple Purple' was damaged. Under these conditions, seedlings of LS1860, LS1903, LS1911, and LS1934 with average indices below 2.5 were judged to be highly resistant to the two strains of inocula. The index of LS1934 was 1.63, a value lower than that of 'Dingaras Multiple Purple' (2.17). Thus, the former should be more resistant to bacterial wilt than the latter. In other evaluations at the infected field or by the artificial inoculation, LS1934 always showed resistance to bacterial wilt (data not shown). LS1934 plants were resistant to Fusarium wilt as well as to bacterial wilt (Table 4 ).

In the field evaluation, more than $60 \%$ of the accessions were resistant to bacterial wilt; some displayed a higher resistance in the artificial inoculation when the selection pressure was more severe. The presence of a high level of bacterial wilt resistance among the Malaysian accessions may be ascribed to the occurrence of the pathogen of bacterial wilt under the climatic conditions pre- 
Table 2. Evaluation of resistance to bacterial wilt in eggplant accessions collected in Malaysia, indexed 10 weeks after trans. planting to an infected field.

\begin{tabular}{|c|c|c|c|c|c|c|c|c|c|c|c|c|c|}
\hline \multirow{2}{*}{ Accession } & \multicolumn{6}{|c|}{ Disease Index ${ }^{2}$} & \multirow{2}{*}{ Accession } & \multicolumn{6}{|c|}{ Disease Index ${ }^{2}$} \\
\hline & 0 & 1 & 2 & 3 & 4 & Ave. ${ }^{y}$ & & 0 & 1 & 2 & 3 & 4 & Ave. ${ }^{y}$ \\
\hline LS 1859 & 8 & 1 & & & 1 & 0.50 & LS 2249 & & & & & 10 & 4.00 \\
\hline LS 1860 & 10 & & & & & 0.00 & LS 2252 & 1 & & & & & 0.00 \\
\hline LS 1883 & & 1 & 1 & & 8 & 3.50 & LS 2254 & 10 & & & & & 0.00 \\
\hline LS 1884 & & 1 & 2 & 1 & 6 & 3.20 & LS 2255 & 7 & & 1 & & 2 & 1.00 \\
\hline LS 1891 & 7 & & & 1 & 2 & 1.10 & LS 2262 & & & 1 & 2 & 7 & 3.60 \\
\hline LS 1896 & 5 & & & & & 0.00 & LS 2263 & 4 & 2 & & 1 & 3 & 1.70 \\
\hline LS 1902 & 1 & & 1 & 1 & 7 & 3.30 & LS 2264 & 1 & 1 & 1 & & 7 & 3.20 \\
\hline LS 1.903 & 10 & & & & & 0.00 & LS 2271 & 10 & & & & & 0.00 \\
\hline LS 1907 & & & & & 10 & 4.00 & LS 2280 & & & & & 10 & 4.00 \\
\hline LS 1910 & & 1 & & & 9 & 3.70 & LS 2281 & & & & & 2 & 4.00 \\
\hline LS 1911 & 10 & & & & & 0.00 & LS 2282 & & & & & 10 & 4.00 \\
\hline LS 1913 & 10 & & & & & 0.00 & LS 2283 & 9 & & & & & 0.00 \\
\hline LS 1931 & 9 & & & & 1 & 0.40 & LS 2284 & & & 2 & & 8 & 3.60 \\
\hline LS 1934 & 10 & & & & & 0.00 & LS 2287 & & 1 & & & 9 & 3.70 \\
\hline LS 1949 & 9 & & & & & 0.00 & LS 2288 & & & & & 10 & 4.00 \\
\hline LS 1951 & 10 & & & & & 0.00 & LS 2382 & 5 & 4 & 1 & & & 0.60 \\
\hline LS 1998 & 3 & & 2 & & 5 & 2.40 & LS 2397 & 10 & & & & & 0.00 \\
\hline LS 1999 & 2 & 1 & 3 & 1 & 2 & 1.80 & LS 2413 & 2 & & & & 8 & 3.20 \\
\hline LS 2014 & & & 1 & & 1 & 3.00 & LS 2414 & & & & & 10 & 4.00 \\
\hline LS 2208 & 9 & 1 & & & & 0.10 & LS 2429 & 6 & 1 & 1 & & 2 & 1.10 \\
\hline LS 2209 & 10 & & & & & 0.00 & LS 2433 & 1 & & & & & 0.00 \\
\hline LS 2217 & 3 & 1 & 2 & & 4 & 2.10 & LS 2434 & 7 & & & & 2 & 0.89 \\
\hline LS 2219 & 10 & & & & & 0.00 & LS 2435 & 10 & & & & & 0.00 \\
\hline LS 2223 & 1 & 1 & 2 & 1 & 5 & 2.80 & LS 2436 & 9 & & & & 1 & 0.40 \\
\hline LS 2227 & 4 & 2 & 1 & & 2 & 1.30 & LS 2439 & 10 & & & & & 0.00 \\
\hline LS 2228 & 7 & & 1 & 1 & 1 & 0.90 & LS 2440 & 9 & & & & 1 & 0.40 \\
\hline LS 2234 & 2 & 1 & 1 & & 6 & 2.70 & Asist ${ }^{x}$ & & & 2 & & 7 & 3.60 \\
\hline LS 2235 & & & & & 10 & 4.00 & $F_{1}$ Meet $^{x}$ & & & & 1 & 9 & 3.90 \\
\hline LS 2237 & 7 & 2 & 1 & & & 0.40 & $F_{1}$ Caravan $^{x}$ & & & & & 10 & 4.00 \\
\hline LS 2240 & & & & & 10 & 4.00 & I. H. G. ${ }^{w}$ & & & & & 10 & 4.00 \\
\hline LS 2242 & & & & & 10 & 4.00 & D. M.P. ${ }^{v}$ & 10 & & & & & 0.00 \\
\hline LS 2245 & & 1 & & & 9 & 3.90 & Money Maker & & & & & 10 & 4.00 \\
\hline LS 2247 & 6 & & & & 4 & 1.60 & & & & & & & \\
\hline
\end{tabular}

Foliar symptom scale, higher numbers indicate severer disease.

y Average value of disease indices of each accession.

$\times F_{1}$ between $S$. aethiopicum (syn. S. integrifolium) and S. melongena.

"Italian Happy Globe (S. aethiopicum).

v Dingaras Multiple Purple.

vailing in tropical areas, such as Southeast Asia.

\section{Verticillium wilt}

Disease indices of the susceptible check 'Money Maker No. 2' were 3.63 (test No. IV) and 3.58 (test No. V), indicating a lack of resistance to Verticillium wilt. The rootstocks 'Italian Happy Globe' and 'Assist', which were considered to be susceptible, showed a relatively high level of resistance equal to that of the resistant ' $F_{1}$ Meet' and ' $F_{1}$
Caravan'. Our results indicate that the inoculations were performed adequately. It was suggested that the Verticillium wilt resistance of the rootstocks was derived from $S$. aethiopicum. Because all the accessions were either $S$. aethiopicum varieties or hybrids between $S$. aethiopicum and $S$. melongena (Table 5).

None of the eggplant accessions collected in Malaysia showed immunity or complete resistance to Verticillium wilt. Disease indices of 45 acces- 
Table 3. Evaluation of resistance to bacterial wilt in greenhouse-grown eggplant accessions collected in Malaysia. Indexed 11 weeks after $\mathrm{t}$ inoculation.

\begin{tabular}{|c|c|c|c|c|c|c|c|c|c|c|c|c|c|}
\hline \multirow{3}{*}{ Accession } & \multicolumn{6}{|c|}{ Bacterial strain EBw 89} & \multicolumn{6}{|c|}{ Bacterial strain E8750 } & \multirow{3}{*}{$\begin{array}{l}\text { Average } \\
\text { value of } \\
\text { disease } \\
\text { index }\end{array}$} \\
\hline & \multicolumn{6}{|c|}{ Disease Index ${ }^{z}$} & \multicolumn{6}{|c|}{ Disease Index ${ }^{z}$} & \\
\hline & 0 & 1 & 2 & 3 & 4 & Ave. ${ }^{y}$ & 0 & 1 & 2 & 3 & 4 & Ave. ${ }^{y}$ & \\
\hline LS 1860 & 3 & & & & 9 & 3.00 & 7 & & & & 5 & 1.67 & 2.34 \\
\hline LS 1896 & & & & & 2 & 4.00 & & & & & 2 & 4.00 & 4.00 \\
\hline LS 1903 & 7 & & & & 5 & 1.67 & 3 & & & & 9 & 3.00 & 2.34 \\
\hline LS 1911 & 9 & & & & 3 & 1.00 & 4 & & & & 8 & 2.67 & 1.87 \\
\hline LS 1913 & 2 & & & & 10 & 3.33 & 1 & & & & 11 & 3.67 & 3.50 \\
\hline LS 1934 & 6 & & & 1 & 5 & 1.92 & 8 & & & & 4 & 1.33 & 1.63 \\
\hline LS 2208 & 5 & & & & 7 & 2.33 & 4 & & & & 8 & 2.67 & 2.50 \\
\hline LS 2209 & 3 & & & & 9 & 3.00 & 2 & & & 1 & 9 & 3.25 & 3.13 \\
\hline LS 2219 & 1 & & & & 11 & 3.67 & 6 & & & & 6 & 2.00 & 2.84 \\
\hline LS 2252 & 3 & & & 1 & 8 & 2.92 & 3 & & & & 9 & 3.00 & 2.96 \\
\hline LS 2254 & 1 & & & & 11 & 3.67 & & & & & 12 & 4.00 & 3.84 \\
\hline LS 2271 & 2 & & & & 10 & 3.33 & 5 & & & & 7 & 2.33 & 2.83 \\
\hline LS 2283 & 3 & & & & 9 & 3.00 & 4 & & & 1 & 7 & 2.58 & 2.79 \\
\hline LS 2397 & 1 & & & & 11 & 3.67 & 1 & & & & 11 & 3.67 & 3.67 \\
\hline LS 2435 & 1 & & & & 11 & 3.67 & 1 & & & 1 & 10 & 3.58 & 3.63 \\
\hline LS 2439 & & & & & 12 & 4.00 & & & & & 12 & 4.00 & 4.00 \\
\hline Asist $^{x}$ & 4 & & & 1 & 7 & 2.58 & 3 & & & & 9 & 3.00 & 2.79 \\
\hline$F_{1}$ Meet $^{x}$ & & & & & 12 & 4.00 & 2 & & & & 8 & 3.20 & 3.60 \\
\hline D. M. P. ${ }^{w}$ & 6 & & & & 6 & 2.00 & 5 & & & & 7 & 2.33 & 2.17 \\
\hline Money Maker No.2 & 1 & & 1 & & 10 & 3.50 & 1 & & & & 11 & 3.67 & 3.59 \\
\hline Nakate Shinkuro & & & & & 12 & 4.00 & 2 & & & & 10 & 3.33 & 3.67 \\
\hline
\end{tabular}

2 Foliar symptom scale, higher numbers indicate severer disease.

$y$ Average value of disease indices of each accession.

$x \quad F_{1}$ between S.aethiopicum (syn. S. integrifolium) and S. melongena.

w Dingaras Multiple Purple.

Table 4. Indices of resistance to Fusarium wilt, evaluated 4 weeks after inoculation.

\begin{tabular}{lrrrrrr}
\hline \hline & \multicolumn{5}{c}{ Disease Index $^{2}$} \\
\cline { 2 - 6 } Accession & 0 & 1 & 2 & 3 & 4 & Ave. $^{y}$ \\
\hline LS 1934 & 29 & & 1 & 0.13 \\
LS 2436 & 25 & & 0 & 0.00 \\
'Nantou Qie' (LS 96) & 0 & & 15 & 4.00 \\
\hline$z \quad$ Foliar symptom scale, higher numbers indicate severer \\
disease.
\end{tabular}

sions of the Malaysian accessions exceeded 3.00 , which indicated that they were not resistant to Verticillium wilt. However, the 10 accessions, LS1910, LS2014, LS2263, LS2382, LS2429, LS2433, LS2434, LS2436, LS2439, and LS2440, showed a partial resistance in the first test (Table
$6)$.

To confirm the resistance to Verticillium wilt, several tests were performed in the resistant accessions (Table 6) which revealed that LS2436 posessed relatively high resistance; it was also resistant to bacterial wilt (Table 2) and to Fusarium wilt (Table 4).

In the evaluation of Verticillium wilt, more than $80 \%$ (45 out of 56 accessions) of the Malaysian accessions were not resistant, presumably because Verticillium wilt does not occur in Malaysia.

In this study, we were able to identify two new resistant accessions LS1934 (bacterial wilt and Fusarium wilt resistant) and LS2436 (Verticillium wilt, bacterial wilt and Fusarium wilt resistant). Fruit of LS1934 are reddish-purple when immature and globular $(8 \mathrm{~cm}$ in width $\times 9 \mathrm{~cm}$ in length); fruit of LS2436 are green and, likewise, globular (6 $\mathrm{cm}$ in width $\times 6 \mathrm{~cm}$ in length). Although the 
Table 5. Evaluation of resistance to Verticillium wilt in eggplant accessions collected in Malaysia.

\begin{tabular}{|c|c|c|c|c|c|c|c|c|c|c|c|c|c|c|c|}
\hline \multirow{2}{*}{$\begin{array}{l}\text { Test } \\
\text { No. }{ }^{z}\end{array}$} & \multirow{2}{*}{ Accession } & \multicolumn{6}{|c|}{ Disease Index ${ }^{y}$} & \multirow{2}{*}{$\begin{array}{l}\text { Test } \\
\text { No. }^{2}\end{array}$} & \multirow{2}{*}{ Accession } & \multicolumn{6}{|c|}{ Disease Index ${ }^{y}$} \\
\hline & & 0 & 1 & 2 & 3 & 4 & Ave $^{x}$ & & & 0 & 1 & 2 & 3 & 4 & Ave. ${ }^{x}$ \\
\hline \multirow[t]{17}{*}{ I } & LS 1859 & & & & 2 & 8 & 3.80 & III & LS 2255 & & & & & 5 & 4.00 \\
\hline & LS 1860 & & & 2 & 4 & 4 & 3.20 & & LS 2262 & 1 & & & & 5 & 3.33 \\
\hline & LS 1883 & & & 1 & 3 & 6 & 3.50 & & $\underline{\text { LS } 2263}$ & & 1 & 1 & 2 & 1 & 2.60 \\
\hline & LS 1891 & & & & 2 & 8 & 3.80 & & $\overline{L S} 2264$ & & & & 1. & 2 & 3.70 \\
\hline & LS 1902 & & & 1 & 1 & 8 & 3.70 & & LS 2271 & & & & & 6 & 4.00 \\
\hline & LS 1903 & & & 2 & 3 & 5 & 3.30 & & LS 2280 & & & & & 6 & 4.00 \\
\hline & LS 1907 & & & 1 & 5 & 4 & 3.30 & & LS 2281 & & & & & 6 & 4.00 \\
\hline & $\underline{\operatorname{LS} 1910^{\mathrm{w}}}$ & & 2 & 3 & 2 & 3 & 2.60 & & LS 2282 & & & & & 5 & 4.00 \\
\hline & $\overline{\operatorname{LS} 1911}$ & & & 1 & 4 & 5 & 3.40 & & LS 2283 & & & & 1 & 4 & 3.80 \\
\hline & LS 1913 & & & & 5 & 5 & 3.50 & & LS 2284 & & & 1 & 1 & 3 & 3.40 \\
\hline & LS 1931 & & 1 & 1 & 1 & 7 & 3.40 & & LS 2287 & & & 1 & 1 & 4 & 3.50 \\
\hline & LS 1934 & & & & 3 & 6 & 3.67 & & LS 2288 & & & & & 4 & 4.00 \\
\hline & LS 1949 & & & 1 & 4 & 3 & 3.25 & & & & & & & & \\
\hline & LS 1951 & & & 2 & 3 & 5 & 3.30 & IV & $\underline{\text { LS } 2382}$ & & & 3 & 2 & 1 & 2.67 \\
\hline & LS 1998 & & & & 1 & 9 & 3.90 & & LS 2397 & & & & 1 & 9 & 3.90 \\
\hline & LS 1999 & & 1 & & 2 & 5 & 3.38 & & LS 2413 & 1 & & 1 & & 8 & 3.40 \\
\hline & & & & & & & & & LS 2414 & & & 2 & 1 & 6 & 3.44 \\
\hline \multirow[t]{4}{*}{ II } & LS 1884 & & & 2 & 4 & 1 & 2.86 & & $\underline{\text { LS } 2429}$ & 2 & 4 & 2 & & & 1.90 \\
\hline & LS 1896 & & & & 2 & 2 & 3.50 & & $\overline{\operatorname{LS} 2434}$ & 2 & 3 & 1 & 1 & 6 & 2.46 \\
\hline & $\underline{\text { LS } 2014}$ & & 2 & & 1 & 2 & 1.59 & & LS 2435 & & & 2 & 6 & 2 & 3.00 \\
\hline & & & & & & & & & $\underline{L S} 2436$ & & 2 & 5 & 2 & 1 & 2.20 \\
\hline \multirow[t]{14}{*}{ III } & LS 2206 & & & & & 5 & 4.00 & & $\overline{\mathrm{LS} 2439}$ & 1 & & 2 & 1 & & 1.75 \\
\hline & LS 2208 & & & & & 6 & 4.00 & & $\underline{\operatorname{LS} 2440}$ & 1 & & 2 & 4 & 2 & 2.67 \\
\hline & LS 2209 & & & & & 6 & 4.00 & & $\overline{\text { Asist }^{v}}$ & 1 & 5 & 3 & & & 1.22 \\
\hline & LS 2217 & & & & & 6 & 4.00 & & $F_{1}$ Meet $^{v}$ & 2 & 4 & 2 & & & 1.00 \\
\hline & LS 2219 & & & 1 & 2 & 3 & 3.33 & & $\mathrm{~F}_{1}$ Caravan $^{\mathrm{v}}$ & & 6 & 2 & & & 1.25 \\
\hline & LS 2223 & & & & 3 & 3 & 3.50 & & I. H. G. ${ }^{u}$ & & 5 & 3 & & & 1.38 \\
\hline & LS 2227 & & & & & 2 & 4.00 & & B. B. ${ }^{t}$ & 1 & 2 & 2 & 1 & 2 & 2.13 \\
\hline & LS 2228 & & & & & 6 & 4.00 & & M. M. ${ }^{s}$ & & & 1 & 1 & 6 & 3.63 \\
\hline & LS 2234 & & & & & 6 & 4.00 & & 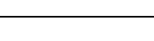 & & & & & & \\
\hline & LS 2235 & & & & & 6 & 4.00 & V & $\underline{\text { LS } 2433}$ & 1 & 2 & & & & 0.67 \\
\hline & LS 2237 & & & & & 6 & 4.00 & & $\overline{F_{1} \text { Meet }}$ & & & 4 & 5 & 3 & 2.92 \\
\hline & LS 2240 & & 1 & & 1 & 3 & 3.20 & & $\mathrm{~F}_{1}$ Caravan & & 1 & 6 & 2 & 3 & 2.58 \\
\hline & LS 2242 & & & 1 & & 3 & 3.50 & & M. M. & & 1 & 1 & & 10 & 3.58 \\
\hline & LS 2254 & & & & 2 & 3 & 3.60 & & & & & & & & \\
\hline
\end{tabular}

2 Schedule of tests are given in Table 1.

y Foliar symptom scale, higher numbers indicate severer disease.

$x$ Average value of disease indices of each accession.

w The accessions underlined are estimated to be resistant based on their average disease indices.

$\checkmark F_{1}$ between S. aethiopicum (syn. S. integrifolium) and S. melongena.

u Italian Happy Globe (S. aethiopicum).

t Black Beauty.

5 Money Maker No.2.

growth of both accessions is relatively slow and the yield is relatively low (authors' observation), they could serve as breeding materials for resistance to Verticillium wilt, Fusarium wilt and bacterial wilt. We are now planning to release a rootstock variety 'Daitaro'. It is a $F_{1}$ hybrid between LS1934 and 'WGCR 112-8' (Indian variety. with bacterial wilt resistance) which shows a high resistance to bacterial wilt and to Fusarium wilt. Furthermore, its performance as a rootstock (yield and fruit quality of grafted plants) is superior to that of other rootstock varieties. Analysis of the inheritance of the resistance should be carried out for further breeding programmes. 
Table 6. Evaluation of resistance to Verticillium wilt in accessions estimated to be resistant.

\begin{tabular}{|c|c|c|c|c|c|c|c|c|c|c|}
\hline \multirow{2}{*}{\multicolumn{2}{|c|}{$\begin{array}{l}\text { Test } \\
\text { No. }{ }^{z}\end{array}$}} & \multirow{2}{*}{$\begin{array}{l}\text { Ref. } \\
\text { No. }{ }^{y}\end{array}$} & \multirow{2}{*}{ Accession } & \multirow{2}{*}{$\begin{array}{l}\text { Number of } \\
\text { Tests }\end{array}$} & \multicolumn{6}{|c|}{ Disease Index ${ }^{x}$} \\
\hline & & & & & 0 & 1 & 2 & 3 & 4 & Ave. ${ }^{w}$ \\
\hline \multirow{9}{*}{\multicolumn{2}{|c|}{ VI }} & IV & $\underline{\operatorname{LS} 1910^{\circ}}$ & 2 & & 1 & 3 & 4 & 2 & 2.70 \\
\hline & & & $\overline{\operatorname{LS} 2014}$ & 2 & 2 & & & & 4 & 2.67 \\
\hline & & & $\overline{\text { LS } 2263}$ & 2 & & & 5 & 4 & 1 & 2.60 \\
\hline & & & $\overline{\text { Asist }^{u}}$ & & 1 & 5 & 3 & & & 1.22 \\
\hline & & & $F_{1}$ Meet $^{u}$ & & 2 & 4 & 2 & & & 1.00 \\
\hline & & & $F_{1}$ Caravan & & & 6 & 2 & & & 1.25 \\
\hline & & & I. H. G. ${ }^{t}$ & & & 5 & 3 & & & 1.38 \\
\hline & & & B. B. ${ }^{s}$ & & 1 & 2 & 2 & 1 & 2 & 2.13 \\
\hline & & & M. M. ${ }^{r}$ & & & & 1 & 1 & 6 & 3.63 \\
\hline \multirow{8}{*}{\multicolumn{2}{|c|}{ VI }} & & LS 2014 & 3 & & 1 & 4 & 7 & 6 & 3.00 \\
\hline & & & LS 2263 & 3 & & & 2 & 7 & 7 & 3.31 \\
\hline & & & $\underline{\operatorname{LS} 2436}$ & 2 & & 7 & 5 & 3 & 3 & 2.11 \\
\hline & & & $\overline{F_{1} \text { Meet }}$ & & & 12 & 6 & 1 & 1 & 1.55 \\
\hline & & & $F_{1}$ Caravan & & & 4 & 8 & 2 & 1 & 1.00 \\
\hline & & & I. H. G. & & & 1 & 9 & 7 & & 2.35 \\
\hline & & & M. M. & & & & 2 & 7 & 8 & 3.35 \\
\hline & & & N.S. ${ }^{9}$ & & & & & 5 & 11 & 3.69 \\
\hline \multirow{8}{*}{\multicolumn{2}{|c|}{ 讲 }} & & LS 1910 & 3 & & & 4 & 5 & 9 & 3.28 \\
\hline & & & LS 2382 & 2 & & & 1 & 2 & 17 & 3.80 \\
\hline & & & LS 2429 & 2 & & & 2 & 2 & 8 & 3.50 \\
\hline & & & LS 2439 & 2 & & & 1 & 1 & 4 & 3.50 \\
\hline & & & LS 2440 & 2 & & & 1 & 5 & 4 & 3.30 \\
\hline & & & $F_{1}$ Caravan & & & & 6 & 3 & & 2.33 \\
\hline & & & I. H. G. & & & & 1 & 1 & 3 & 3.40 \\
\hline & & & M. M. & & & & & 6 & 14 & 3.70 \\
\hline \multirow[t]{4}{*}{$\mathbb{X}$} & & V & LS 2436 & 3 & & 9 & 2 & & 1 & 1.42 \\
\hline & & & $\overline{\overline{F_{1} \text { Meet }}}$ & & & & 4 & 5 & 3 & 2.92 \\
\hline & & & $F_{1}$ Caravan & & & 1 & 6 & 2 & 3 & 2.58 \\
\hline & & & M. M. & & & 1 & 1 & & 10 & 3.58 \\
\hline \multirow[t]{4}{*}{$X$} & & & LS 2433 & 2 & & 1 & 4 & 4 & 11 & 3.25 \\
\hline & & & LS 2436 & 4 & & 13 & 3 & 2 & 2 & 1.65 \\
\hline & & & $\overline{\overline{\text { I. H. G. }}}$ & & 2 & 1 & 7 & 9 & 1 & 2.35 \\
\hline & & & N.S. & & & & & & 20 & 4.00 \\
\hline \multicolumn{11}{|c|}{$=$ Schedule of tests are given in Table 1} \\
\hline \multicolumn{11}{|c|}{$\begin{array}{l}\text { The tests were carried out simultaneously with the reference number test indicated in Table } 5 . \\
\text { Foliar symptom scale, higher numbers indicate severer disease. } \\
\text { Average value of disease indices of each accession. } \\
\text { The underlined accessions are estimated to be resistant based on their average disease indices. } \\
\text { Accessions with thick line ( } \\
\text { resistant based on two or more evaluations. }\end{array}$} \\
\hline
\end{tabular}

Note : A seed sample for research purposes is available on NIVOT (Dr. Shinji MONMA).

\section{Literature Cited}

Goth, R. W. and R. E. Webb. 1981. Sources and genetics of host resistance in vegetable crops. $p$. 
377-411. In : M. E. Mace, A. A. Bell and C. H. Beckman (eds.). Fungal wilt disease of plants. Academic Press, New York.

Kelman, A. 1953. The bacterial wilt caused by Pseudomonas solanacearum. North Carolina Agric. Exp. Stn. Tech. Bull. $99: 1-194$.

Nath, P. 1975. Breeding vegetable crops for resistance to disease in India. SABRAO Journal $7: 7-11$.

Schnathorst, W. C. 1981. Life cycle and epidemiology of Verticillium. p. 81-111. In : M. E. Mace, A. A. Bell and C. H. Beckman, (eds.). Fungal wilt dis- ease of plants. Academic Press, New York.

Snyder, W. C. and S. N. Smith. 1981. Current status. p. 25-49. In : M. E. Mace, A. A. Bell and C. H. Beckman (eds.). Fungal wilt disease of plants. Academic Press, New York.

Wakimoto, S. 1962. Studies on the multiplication of OP1 phage (Xanthomonas oryzae bacteriophage) 1 . One step growth experiment under various conditions. Sci. Bull. Fac. Agr. Kyushu Univ. 15 : $151-160$.

マレイシアで収集したナス (Solanum melongena L.)の青枯病抵抗性および半身萎ちょう病抵抗性

坂田好輝 ·門馬信二・成河智明 $*$ 小 小餅昭二**

野菜・茶業試験場 514-23 三重県安芸郡安䟴町

\section{摘 要}

著者らは, マレイシア農業開発研究所 (MARDI) の協力によってマレイシアより収集した 60 系統のナ ス (Solanum melongena) について, 青枯病および半 身萎ちょう病に対する抵抗性素材を見い出すため，両 病害に対する抵抗性検定を実施した。また有望系統に 関しては半枯病抵抗性検定を実施した。

1）青枯病污染围場を用いた検定の結果，供試した ナス系統の約 $60 \%$ が抵抗性を示した。ささらに、これ らの抵抗性系統の中でより高度な抵抗性を有する系統 を選抜するため，強度の接種条件（菌濃度 1.5 - 3.0 $\left.\times 10^{10} \mathrm{cell} \cdot \mathrm{m} l^{-1}\right)$ で幼植物検定を行ったところ, LS 1934 は最も高度な抵抗性を示した。

2) 半身萎ちょう病の幼植物接種検定の結果, 供試
した約 80\%の系統がり病性であり，免疫あるいは完 全な抵抗性を示した系統は見い出せなかった．部分的 な抵抗性を示した系統の抵抗性程度には差異が認めら れ，複数回の再検定により，LS 2436 は相対的に高い 抵抗性を示すことが確認された。なお，LS 2436 は青 枯病污染國場検定で青枯病にも抵抗性であった。

3）LS 1934 およびLS 2436 の半枯病抵抗性を調べ るために，幼植物接種検定を行ったところ，両系統と もに抵抗性であることが判明した。

以上，青枯病㧍よび半枯病に抵抗性を示すLS 1934, 半身萎ちょう病，青枯病及び半枯病に抵抗性を示す LS 2436 の 2 系統の有望な育種素材を, マレイシアで 収集したナスの中から見い出すことができた。

\footnotetext{
*現在：三井東圧化学 100 東京千代田区㩔ヶ関.

**現在：北海製罐研究所 063 札幌市西区宮の沢.
} 